Oral Section

\title{
Summary of four scientific studies on Arsenicum album high dilution effect against Arsenic intoxication in mice
}

\author{
Naoual Boujedaini ${ }^{1}$, Laurence Terzan ${ }^{1}$, Anisur Rahman Khuda-Bukhsh ${ }^{2}$ \\ ${ }^{1}$ Laboratoires Boiron, 20 rue de la Libération, 69110 Sainte-Foy-lès-Lyon, France. \\ ${ }^{2}$ Cytogenetics and Molecular Biology Laboratory, University of Kalyani, Kalyani , India
}

\begin{abstract}
Background: Groundwater arsenic affects millions of people in about 20 countries. In West Bengal (India) and Bangladesh alone over 100 million people are exposed. The arsenic concentration in contaminated groundwater in Bangladesh was above the maximum permissible level of $0.05 \mathrm{mg} / \mathrm{l}$ as recommended by WHO for developing countries [1]. Drinking water is not the only source of poisoning. In arsenic contaminated areas, crops, vegetables, cereals, poultry, cattle, etc, also contain traces of arsenic. Chronic arsenic intoxication has been associated with several diseases such as melanosis, leuco-melanosis, hyperkeratosis, oedema, skin cancer...

Cazin et al [2], have demonstrated the effect of high dilutions of arsenic compounds. They noted increased arsenic elimination from blood through urine and faeces in intoxicated rats. According to these research, the aim of Khuda Buksh studies [3-4-5] was to investigate whether high dilution Arsenicum album have any effect on arsenic accumulation in different tissues and to understand also how this high dilution could produce a protective effect on all the different organs.
\end{abstract}

Methodology: Firstly, the effect of Arsenicum album $30 \mathrm{cH}$ on the amount of arsenic accumulation was determined by spectrophotometric analysis in four tissues namely liver, kidney and testis in mice intoxicated by arsenic. The protective effect in chronic and acute arsenic intoxicated mice of Arsenicum Album $6 \mathrm{cH}, 30 \mathrm{cH}$ and $200 \mathrm{cH}$ has been evaluated using not only the activities of enzymatic and biomarker toxicity (aspartate amino transferase (AST), alanine amino transferase (ALT), acid phosphatase (AcP), alkaline phosphatase (AlkP), lipid peroxidation (LPO) and reduced glutathione (GSH)) but also the cytogenetical parameters (chromosome aberrations (CA), mitotic index (MI), sperm head anomaly (SHA) etc., ). Because, it is well demonstrated that these enzymes biomarkers reflect the degree of hepatotoxicity and oxidative stress caused by arsenic intoxication.

Results: Compared to controls, Arsenicum album 30cH induced a significant decrease in accumulation of arsenic in 4 tissues namely liver, spleen, kidney and testis in intoxicated mice. In addition, both Arsenicum album $6 \mathrm{cH}, 30 \mathrm{cH}$ and $200 \mathrm{cH}$ reduced chromosome aberrations, sperm head abnormality frequencies and activities of acid and alkaline phosphatases, aspartate and alanine aminotransferases and lipid peroxidation, while mitotic index and activities of glutathione, catalase and succinate dehydrogenase were increased compared to controls.

Conclusion: Altogether, these results provide evidence of protective potentials of the Arsenicum album dilution against acute and chronic arsenic intoxication in mice. They also offer a new hypothesis that the 
mechanism of the homeopathic dilution could act through regulation of expression of certain genes. This explanation seems to be plausible because all biomarker tests are regulated by specific genetic regulatory mechanisms [6].

keywords: Arsenicum album, arsenic intoxication, enzymatic and biomarker toxicity.

\section{References:}

[1] WHO. WHO Guidelines for Drinking Water Quality, Vol. 2, 2nd edition. Geneva: WHO, 1996, 940-949.

[2] Cazin JC, Cazin M, Gaborit JL, Chaoui A, Boiron J, Belon P, et al. A study of the effect of decimal and centesimal dilutions of arsenic on the retention and mobilization of arsenic in the rat. Hum Toxicol 1987;6:315-320.

[3] Mitra K, Kundu SN, Khuda-Bukhsh AR. Efficacy of a potentized homoeopathic drug (Arsenicum Album30) in reducing toxic effects produced by of arsenic trioxide in mice. I. On rate accumulation of arsenic in certain vital organs. Comp Ther Med 1998;6:178-184.

[4] Pathikrit Banerjee. Evidences of Protective Potentials of Microdoses of Ultra-high Diluted Arsenic Trioxide in Mice Receiving Repeated Injections of Arsenic Trioxide. eCAM 2009; 1-10.

[5] Pathikrit Banerjee, Comparative Efficacy of Two Microdoses of a Potentized Homeopathic Drug, Arsenicum Album, to Ameliorate Toxicity Induced by Repeated Sublethal Injections of Arsenic Trioxide in Mice. Pathobiology 2008;75:156-170.

[6] Khuda-Bukhsh AR. Potentized homeopathic drugs act through regulation of gene expression: a hypothesis to explain their mechanism and pathways of action in vivo. Comp Ther Med 1997;5:43-46

\section{(c)) BY-NC-ND Licensed to GIRI}

Support: authors declare that this study received funding from Boiron

Conflict of interest: authors declare there is no conflict of interest

Received: 01 June 2012; Revised: 09 August 2012; Published: 30 September 2012.

Correspondence author: Naoual Boujedaini: Naoual.boujedaini@boiron.fr

How to cite this article: Boujedaini N, Terzan L, Khuda-Bukhsh AR. Summary of four scientific studies on Arsenicum album high dilution effect against Arsenic intoxication in mice. Int J High Dilution Res [online]. 2012 [cited YYYY Month dd]; 11(40):150-151. Proceedings of the XXVI GIRI Symposium; 2012 Sep 20-22; Florence (Italy). GIRI; 2012; Available from: http://www.feg.unesp.br/ ojs/index.php/ijhdr/article/view/606/584 